\title{
Author Correction: Clinical and serological evaluation of capybaras (Hydrochoerus hydrochaeris) successively exposed to an Amblyomma sculptum-derived strain of Rickettsia rickettsii
}

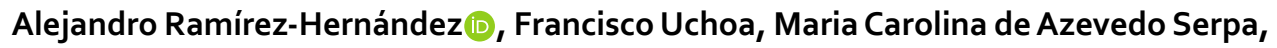 \\ Lina C. Binder, Alessandra Castro Rodrigues, Matias P. J. Szabó, Andrea Fogaça, \\ Celso Eduardo Souza \& Marcelo B. Labruna
}

Correction to: Scientific Reports https://doi.org/10.1038/s41598-020-57607-5, published online 22 January 2020

This Article contains an error in the Figure legends of Figure 6 and Figure 7. The legends of these Figures were inadvertently switched.

The legend of Figure 6:

"Rickettsia rickettsii antibody titres (IFA) after multiple infections with R. rickettsii (strain ITU) via tick exposures, in capybaras no. 1, 4 and 5. Dashed arrows indicate 2nd, 3rd and 4th infection of capybara no. 1 at 120, 248 and 475 days post primary infection (DPI), respectively. Straight arrow indicates 2nd infection of capybaras no. 4 and 5, 227 DPI. This figure has been published within the Doctoral Thesis of the first author (A. Ramírez-Hernández), which is available at the University of São Paulo's digital library of Theses and Dissertations: https://teses.usp.br/teses/disponiveis/10/10134/tde-09092019-112817/en.php."

should read:

"Hematological variables evaluated in capybaras (Hydrochoerus hydrochaeris) according to days post primary infection (DPI) with Rickettsia rickettsii (strain Itu) via tick exposure. Capybara numbers 1 (X), 3 (control) $(\Delta)$, $2(+), 3(\bigcirc), 4(\diamond)$ and $5(\square)$. This figure has been published within the Doctoral Thesis of the first author (A. Ramírez-Hernández), which is available at the University of São Paulo's digital library of Theses and Dissertations: https://teses.usp.br/teses/disponiveis/10/10134/tde-09092019-112817/en.php."

The legend of Figure 7:

"Hematological variables evaluated in capybaras (Hydrochoerus hydrochaeris) according to days post primary infection (DPI) with Rickettsia rickettsii (strain Itu) via tick exposure. Capybara numbers 1 (X), 3 (control) $(\Delta)$, $2(+), 3(\bigcirc), 4(\diamond)$ and $5(\square)$. This figure has been published within the Doctoral Thesis of the first author (A. Ramírez-Hernández), which is available at the University of São Paulo's digital library of Theses and Dissertations: https://teses.usp.br/teses/disponiveis/10/10134/tde-09092019-112817/en.php."

should read: 
"Rickettsia rickettsii antibody titres (IFA) after multiple infections with R. rickettsii (strain ITU) via tick exposures, in capybaras no. 1, 4 and 5. Dashed arrows indicate 2 nd, 3rd and 4th infection of capybara no. 1 at 120, 248 and 475 days post primary infection (DPI), respectively. Straight arrow indicates 2 nd infection of capybaras no. 4 and 5, 227 DPI. This figure has been published within the Doctoral Thesis of the first author (A. Ramírez-Hernández), which is available at the University of São Paulo's digital library of Theses and Dissertations: https://teses.usp.br/teses/disponiveis/10/10134/tde-09092019-112817/en.php."

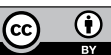

Open Access This article is licensed under a Creative Commons Attribution 4.0 International License, which permits use, sharing, adaptation, distribution and reproduction in any medium or format, as long as you give appropriate credit to the original author(s) and the source, provide a link to the Creative Commons license, and indicate if changes were made. The images or other third party material in this article are included in the article's Creative Commons license, unless indicated otherwise in a credit line to the material. If material is not included in the article's Creative Commons license and your intended use is not permitted by statutory regulation or exceeds the permitted use, you will need to obtain permission directly from the copyright holder. To view a copy of this license, visit http://creativecommons.org/licenses/by/4.0/.

(C) The Author(s) 2020 